\title{
PENGEMBANGAN BAHAN SEJARAH INDONESIA DALAM KURIKULUM PENDIDIKAN SEJARAH DI PERGURUAN TINGGI
}

\author{
Mestika Zed \\ Email: mestikazed17@gmail.com \\ (Guru Besar Jurusan Sejarah Universitas Negeri Padang)
}

\begin{abstract}
Abstrak
Jika benar apa yang dikatakan E.H. Carr, bahwa "sejarah adalah rangkaian proses interaksi terus menerus antara sejarawan dan faktanya, suatu dialog tanpa akhir antara masa kini dan masa silam," maka interaksi dan dialog semacam itu mestinya juga menjadi bahan pertimbangan dalam menyusun bahan sejarah Indonesia dalam kurikulum pendidikan sejarah pada umumnya dan di perguruan tinggi khususnya. Sejak beberapa dekade belakangan wacana tentang penulisan sejarah 'Indonesia-sentris' tampaknya sudah mencapai titik jenuh, meskipun kritik terhadap historiografi Indonesia tetap ada. Kecenderungan ini, tak syak lagi, akan terus berlangsung di masa datang. Sumbangan saya dalam kertas kerja ini berkenaan dengan pertanyaan sederhana, tetapi kiranya juga tidak mudah dijawab: sesudah IDAS apa yang harus dilakukan, khususnya dalam kerangka membenahi bahan kurukulum pendidikan sejarah Indonesia di perguruan tinggi? Pendirian yang ingin dikemukakan dalam risalah sederhana ini ialah bahwa pengajaran sejarah Indonesia sejauh ini tidak mengalami perkembangan berarti- untuk tidak mengatakan mengalami kemacetan, lebih-lebih jika dibandingkan dengan kemajuan dalam penulisan sejarah itu sendiri. Persoalannya tentu amat kompleks. Namun sejauh berkenaan dengan bahan perkuliahan agaknya tidak ada cara lain kecuali dengan menawarkan gagasan kurikulum 'sejarah altenatif' baru di antara sejumlah wacana yang tersedia.
\end{abstract}

Kata kunci: Sejarah Nasional, Indonesia-Sentris, Kurikulum, Sejarah Alternatif.

\section{Wacana Sejarah Indonesia Mutakhir.}

Puncak pencapaian penulisan sejarah Indonesia sentris sampai saat ini diwakili oleh dua karya besar, SNI 6 Jilid $(1975,1981,2008)$ dan IdAS 8 Jilid, plus satu jilid ekstra (jilid 9), (2012). ${ }^{2}$ Kedua buku ini merupakan representasi dari 'sejarah nasional' dalam arti sejarah yang kurang lebih menyediakan versi standar yang bersifat otoritatif tentang sejarah Indonesia dalam rentang waktu yang mencakup dari awal perjalanan sejarah hingga periode terakhir. Kedua karya tersebut tetap penting dengan segala kekuatan dan kelemahannya. Di samping itu,

\footnotetext{
${ }^{1}$ Carr (1987), p. 30.

${ }^{2}$ Sejarah Nasional Indonesia (SNI) 6 Jilid, terbit pertama kali tahun 1975 dan edisi revisi tahun , 1981, dan 2008. Indonesia dalam Arus Sejarah (IdAS), 8 Jilid, plus satu jilid ekstra, Jilid 9 (2012) .

57 | Seminar Nasional Sejarah ke 4 Jurusan Pendidikan Sejarah Universitas Negeri Padang
} 
sedimikian banyak publikasi hasil seminar Seminar Nasional Indonesia (SNI) dengan berbagai istilah, "kongres", "konferensi" - ditambah dengan rangkaian seminar sejarah lokal dan tidak kurang pentingnya seminar kerja sama (joint-seminar) dengan luar negeri (Indonesia-Belanda; Jakarta, Leiden dan New Delhi, India) dan lain-lain seminar pendidikan sejarah. $^{3} \quad$ Jika ditelusur lagi berbagai jenis karya 'sejarah alternatif', suatu kata bersayap yang sering digunakan paska kejatuhan rezim Orde Baru Soeharto untuk menegasikan sejarah yang ditulis di zaman itu, khususnya Jilid 6 SNI, ${ }^{4}$ agaknya tak ada lagi alasan untuk mengeluhkan kekurangan bahan pengajaran sejarah sebagaimana yang sering didengar di masa lalu. Sebuah seminar sejarah nasional dalam rangka memperingati SSN I (1957) dengan mengambil tema besar "Sejarah untuk Kebhinnekaan dan Keindonesiaan. Refleksi 60 tahun Seminar Sejarah Indonesia, 1957-2017” di Yogyakarta, mencerminkan keberagaman bahan dan perspektif mengenai sejarah Indonesia deawsa ini.

Mempelajari kembali keberagaman karya sejarah paska-kolonial, sejarawan Belanda, Klooster (1991) mengelompokkannya ke dalam tiga kategori besar berikut: (1) penulisan sejarah populer (atau sejarah publik); (ii) penulisan sejarah ilmiah dan (iii) sejarah untuk pendidikan (het geschiedenisonderwijs). ${ }^{5} \quad$ Sementara itu Taufik Abdullah terlepas dari sejarah nasional, mengkalsifikasikan ragam penulisan sejarah yang lebih canggih: (i) memoar pribadi; (ii) biografi tokoh; (iii) sejarah lokal; (iv) 'karya rintisan',

(v) sejarah Islam dan akhirnya (vi) IdAS (Indonesia dalam Arus Sejarah). ${ }^{6}$ Tentu saja tidak boleh dilupakan apa yang boleh disebut karya "sejarah revisionis" seperti yang dilakukan oleh Sartono Kartidirdjo dan yang lain-lain, yang kadang cenderung naif dengan menggunakan kata "pelurusan sejarah".

Karya-karya sejarah yang relatif sudah berlimpah ruah itu kiranya menyediakan lebih dari cukup bahan-bahan yang "relevan" - meminjam istilah Taufik Abdullah — untuk mengemas kembali apa yang sebaiknya dirumuskan untuk bahan pengajaran Sejarah Indonesia di perguruan tinggi, khususnya di Lembaga Pendidikan Tenaga Keguruan (LPTK) sebagai "pencetak" guru

\footnotetext{
${ }^{3}$ Lihat misalnya ulasan Kuntowijoyo (2003); Agus Mulyana Dkk (2017) dan tentu saja tak boleh dilupakan Simposuim Pengajaran Sejarah suntingan Restu Gunawan (1995. 1998).

${ }^{4}$ Sekedar contoh lihat misalnya karya Cadwell dan Utrecht (2011), McGregor (2007), Schulte Nordholt (2004), Adam (2001), Opurwanati (2008) dan lain-lain.

${ }^{5}$ Kooster (1985).

${ }^{6}$ Abdullah (2016), Istilah 'karya rintisan' dari saya sendiri berdasarkan penjelasan Taufik Abdullah ketika 58 | Seminar Nasional Sejarah ke 4 Jurusan Pendidikan Sejarah Universitas Negeri Padang
} 
sejarah di sekolah dasar atau menengah.

\section{Isu-Isu Strategis dalam Menyusun Bahan Pengajaran Sejarah Indonesia}

Mencermati kembali perkembangan penulisan sejarah Indonesia selama 60 tahun terakhir maka dapat dilihat bahwa arus utama dalam wacana penulisan sejarah Indonesia ialah isu "Indonesia sentris" sebagai deligitimasi terhadap sejarah Neerlando sentrisme. Meskipun demikian jebakan terhadap konsepsi sejarah Indonesia sentris, menyinggung karya A.B. Lapian tentang sejarah maritim. Seperti yang dikemukakan oleh Bambang Purwanto (2006) mengingatkan kita tentang perlunya memikir ulang konsep Indonesia sentrisme dalam penulisan sejarah, termasuk kekacauan dalam memahami konsep Indonesia sentris itu sendiri, dan dengan demikian juga menetapkan mana yang termasuk fakta-fakta tentang realitas sejarah Indonesia dan mana yang bukan, perlunya memperhatikan kelompok yang termarginalkan dalam sejarah nasional yang selama ini lebih condong memaparkan sejarah elitis, serta pentingnya penggunaan sumber lisan dan seterusnya.

Pengamatan yang lebih kritis akan mengantrakan kita pada kesimpulan yang mengejutkan, bahwa, kedua buku "babon" sejarah nasional yang disebutkan terdahulu: SNI 6 Jilid $(1975,1981,2008)$ dan IdAS 8 Jilid tampaknya belum sepenuhnya bebas dari Belanda sentris atau 'historiografi kolonial'. Dilihat dari segi periodesasi sejarah, misalnya, kedua buku "babon" tersebut, khususnya Jilid 1 sampai jilid 3, sampai tingkat tertentu masih berbau historiografi kolonial, seperti yang ditulis dalam buku-buku sejarah yang ditulis oleh kebanyakan sejarawan atau arkeolog Belanda, yang biasanya menggunakan periode "Zaman Hindu" dan "Zaman Kerajaan-Kerajaan Islam." Walhasil dari segi perspektif buku sejrah nasional hanya menggeser dari perspektif legitimasi "negara kolonial" ke "negara nasional". Walhasil, "these national history textbooks propose nothing new in comparison to perspectives taken within colonial historiography."7 7

Lebih jauh, dialektika sejarah Indonesia sentris pada saat yang sama bergerak dalam subsentrisme dalam setiap zaman. Dengan kekecualian zaman Prasejarah, dalam sejarah Indonesia

\footnotetext{
${ }^{7}$ Suwignyo (2014: 125-6); Schulte Nordholt (2004: pp. 5-4); Purwanta (2018). 
sentris pada kedua buku" babon" tersebut terdapat "Hindu-Buddha sentrisme" dan Islam Sentrisme serta "Eropa v.s. Indonesia sentrisme". Jika demikian halnya, para penulis buku teks sejarah nasional tampak belum sepenuhnya menggunakan teori-teori baru di mana sejarah Indonesia mestinya dipelajari sebagai sejarah pertemuan (encounters), interaksi (interactions) dan pengaruh timbal balik antara aktor pribumi dengan berbagai peradaban yang terjadi selama berabad-abad.

Bertolak dari pengamatan selintas terhadap perkembangan buku teks sejarah Indonesia selama 6o tahun terakhir, khususnya mengenai kedua buku "bobon" yang disebutkan sebelumnya, maka perkenankan saya mendedahkan beberapa isu-isu strategis yang perlu dipertimbangkan dalam menyusun kurikulum sejarah Indonesia di perguruan tinggi berkut ini. Isu-isu strategis maksudnya di sini adalah hal-hal yang mendasar berupa tantangan kritis yang perlu dijawab demi mencapai tujuan penyusunan kurukulum sejarah Indonesia yang lebih baru, dengan menghindari pengulangan kesalahan lama dan dapat memengaruhi mandat, misi, nilainilai, pemangku kepentingan (dosen-mahasiswa dan masyarakat) dalam penguasaan bahanbahan sejarah Indonesia. Beberapa pertimbangan berikut ini hanyalah sekdar usul-usul praktismetodologis.

Pertama, perlu sebuah tim kecil yang akan menghasilkan daftar masalah-masalah strategis yang potensial. Biasanya ini memerlukan waktu yang lebih panjang daripada waktu yang mereka miliki untuk membahas dan menyelesaikannya. Karena itu, daftar harus dikurangi dan diprioritaskan, misalnya sampai 10 buah. Seringkali prosedur "pilihan terpaksa" (forced choice) akan memberi peringkat daftar yang diajukan dengan cepat dan efisien. Pada titik ini masing-masing anggota siap untuk memulai ke diskusi lebih lanjut dalam pemecahan masalah strategis. Misalnya, mulailah dengan pertanyaan pokok, misalnya "Apa yang seharusnya menjadi fokus strategis dalam mengembangkan kurikulum Sejarah Indonesia masa depan bersama para pengajar di LPTK?"

Kedua, erat kaitannya dengan butir pertama ialah bahwa apa paradigma utama yang diikuti karena ini akan menentukan prinsip seleksi topik dan fakta-fakta sejarah Indonesia. Pada hemat saya, paradigma sejarah Indonesia sentris dalam buku teks sejarah 
nasional tetap penting sebagai patokan utama. ${ }^{8}$ Sejarah nasional, mau tidak mau, meletakkan negara-bangsa sebagai unit analisis yang koheren dalam proses jangka panjang, baik prosesproses sosial-budaya, ekonomi, intelektual, maupun hal lainnya yang terkandung di dalamnya. Dalam cara pandang ini maka bangsa adalah subjek sejarah, dan objek perkembangan sejarah yang terkait erat dengan 'drajat integrasi' dari waktu ke waktu (Kartodirdjo 1992). Dengan kata lain, bangsa ini dikatakan telah lama eksis dalam keadaan laten, dan anggotanya dianggap memiliki karakter yang bergerak menuju pembentukan dan "menjadi"sebuah bangsa. Dengan demikian paradigma sejarah nasional tidak bisa menghindari dari penilaian moral dan teleologis, dalam arti tarik-menarik antara kepentingan akademik dan tujuan praktis yang ingin dicapai. Pada periode-periode tertentu komunitas bangsa akan dinilai — dalam semua pengertian istilah - menurut tingkat kemajuan atau penyebab keterbelakangan dan merosotnya ciri nasional dalam wacana sejarah bangsa. ${ }^{9}$

Ketiga, karya-karya sejarah "alternatif" paska kejatuhan Orde Baru Soeharto sampai tingkat tertentu mencerminkan semangat zaman kebebasan Reformasi yang sampai tingkat tertentu "liar' dan/ atau "kebablasan" dan ini sedikit banyak juga terpantul dalam penulisan sejarah zaman ini. Terlebih lagi dengan menjamurnya bermacam jenis media sejarah di era 'digital' akhir-akhir ini, ketika ITC melipatgandakan lalu informasi secara bebas dengan pespektif yang beragam dan cenderung semena- mena. Semua ini memerlukan prinsip seleksi yang ketat, yaitu apa yang pantas untuk dikategorikan ke dalam standar nilai memori kolektif nasional dan mana yang bukan. Dalam ilmu sosial dan humaniora pada umumnya, ada paradigma yang mengatakan bahwa tidak ada pemisahan yang tegas antara dunia fenomenal (subjektif) dan dunia noumenal (objektif). Tidak ada dualisme antara realisme (objektif) dan idealisme (subjektif), antara kebenaran absolut dan pendapat serta tidakan yang tak terhingga. Keduanya mengacu pada kebenaran praktis sebagai kebijaksanaan dalam menyusun strategi kebudayaan manusia Indonesia yang di dalamnya terajut kisah panjang sejarah manusia. $^{10}$ Kenyataan (realitas) sejarah atau peritiwa harus ditemukan faktanya dalam berbagai sumber yang kongkrit yang dapat dilacak lewat peralatan metodologi sejarah. Di situ

\footnotetext{
${ }^{8}$ Lihat misalnya argumen Kartodirdjo (2005); Sulistiyono (2016), pp. 21-22.

9 Sekedar ilustrasi, isu-isu kritis tentang 'Indianisasi' dalam sejarah Indonesia lihat misalnya Rahman(2013) , pp. 56- 64 dan Ismail; tentang sejarah VOC dalam perspektif sejarah sosial lihat Leirissa (1999); tentang isu-isu sejarah kontemporer lihat Abdullah (2015), p179-185.

${ }^{10}$ Peursen (1990); Zed (2012).
}

61 Seminar Nasional Sejarah ke 4 Jurusan Pendidikan Sejarah Universitas Negeri Padang 
peran "nilai" amat penting. Sesuai dengan sifatnya, bahasa sejarah tidak membutuhkan penggunaan berbagai macam konsep yang rumit dan ide yang abstrak, melainkan suatu "ontologi sejarah" empirik. ${ }^{11}$

Keempat, mengkaji ulang periodisasi sejarah Indonesia dengan kompleksitas masalah yang ditimbulkannya. Kita mislanya dapat mempertanyakan apakah benar sub- senterisme seperti tercermin dalam istilah-istilah "zaman Hindu", "zaman Islam", "zaman Belanda", dan "zaman Jepang?" atau "Indonesia-Hindu", Hindu-Jawa", kerajaan-Hindu", "kerajaan Islam". Apa benar apa yang ditulis oleh Dr. Soetjipto Wirjosuparto (alm.) bahwa Indonesia mengalami lima zaman, termasuk "masa pendjadjahan dan menudju zaman kemerdekaan"? Atau menurut Prof. Muh. Yamin yang percaya bahwa bangsa Indonesia mengenal "tiga keperabuan" (kerajaan): Sriwijaya, Majapahit, dan Republik Indonesia sekarang $?^{12}$

Kelima, perlunya mempertimbangkan penyamaan persepsi tentang istilah dan muatan bahan Sejarah Indonesia untuk seluruh jurusan pendiidkan sejarah di LPTK Indonesia dan upaya penyelarasan bahan pengajaran di perguruan tinggi dengan kebutuhan di sekolah. Selaku demikian, bahan sejarah Indonesia nantinya akan berperan sebagai salah satu jembatan untuk mengembangkan aspek keilmuan sejarah pada proses pembelajaran sejarah; dan mengimplementasikan pembelajaran sejarah kritis analitis dan pembelajaran sejarah. $^{13}$

Akhirnya yang keenam, pengembangan berfikir cara sejarah (thinking historically) dalam penyusunan bahan kurikulum sejarah di perguruan tinggi perlu dipertimbangkan. Meskipun tidak mudah, tetapi sebaiknya dan sedapat mungkin haruslah diupayakan. ${ }^{14}$

\section{Pedoman Penyusunan Bahan Sejarah Indonesia}

11 Himpunan informasi tentang buku sumber primer mengenai bahan-bahan sejarah Indonesia dari berbagai sumber, a.l. dapat ditemukan, misalnya, dalam Soedjatmoko (et.al.), edisi terjemahan (1995).

12 Syamsuddin (1998).

${ }^{13}$ Hasan S. Hamid (2008).

${ }^{14}$ Zed (2012).

62 | Seminar Nasional Sejarah ke 4 Jurusan Pendidikan Sejarah Universitas Negeri Padang 
Dalam pengembangan kurikulum pendidikan sejarah Indonesia di perguruan tinggi seyogianya perlu dipertimbangkan kriteria tertentu sesuai dengan kerangka umum yang dikemukaan di atas. Kriteris topik yang signifikan menurut Copuncell (2004) mengandung ciri 5 R's: (i) Remarkable (ii) Resulting in change (iii) Revealing (iv) Remembered (v) Resonant/'ripples'. Kriteria tersebut diturunkan secara konsisten dari kurikulum tujuan masing-masing periode, ${ }^{15}$ dengan tetap mempertimbangkan bahan perkuliahan yang bersifat representatif, esensial, multivalensi, dan menarik. Untuk itu suatu topik akan dipilih dan dikembangkan apabila memenuhi kriteria operasional berikut,

Pertama, seberapa jauh suatu topik yang ada dalam kurikulum tersebut diperlukan sebagai bekal yang efektif, baik untuk memperoleh pengetahuan dan keterampilan dasar guna memperoleh pengetahuan dan keterampilan tertentu, maupun untuk dapat digunakan untuk pencerahan publik apabila terjun ke masyarakat.

Kedua, seberapa jauh suatu topik yang ada dalam kurikulum tersebut dapat berperan sebagai prasyarat dan/atau penunjang bagi topik-topik lain. Peran tersebut tidak hanya dalam rangka pembentukan dan perolehan pengetahuan dan keterampilan dasar yang fungsional untuk belajar di jenjang pendidikan yang lebih tinggi, melainkan juga untuk karier mahasiswa di belakang hari. Meskipun tidak merupakan prioritas untuk kepentingan melanjutkan perkuliahan, kemungkinan suatu topik diperlukan sebagai dasar untuk memberikan nilai tambah bagi topiktopik lain.

Ketiga, seberapa jauh suatu topik yang ada dalam kurikulum tersebut mewakili keterpakaian (applicability) yang lebih luas, sehingga memungkinkan untuk melahirkan inspirasi dan kreativitas dalam rangkai penyesuaian-penyesuain terhadap situasi yang selalu berubah/berkembang apabila terjun ke tengah-tengah masyarakat. Misalnya untuk pengembangan “pariwisata desa sejarah" atau membangun komunitas taman pusaka wisata purbakala dan lainlain.

Keempat, erat kaiotannya dengan butir sebelumnya, seberapa jauh suatu topik yang ada dalam kurikulum tersebut dapat menumbuhkan minat dan daya tarik yang kian besar bagi eksplorasi dan pengembangan pengetahuan lebih lanjut ataupun kegunaan praktis dalam

${ }^{15}$ Beberapa tawaran alternatif periodesasi Sejarah Indoensia a.l. terdapat dalam Djoko Suryo (2009). 63 | Seminar Nasional Sejarah ke 4 Jurusan Pendidikan Sejarah Universitas Negeri Padang 
kehidupan sehari-hari.

Pertimbangan-pertimbangan tersebut di atas merupakan pedoman umum dalam · proses identifikasi topik-topik inti dalam rangka menjamin adanya relevansi kebutuhan dan keterpakaian bahan pendidikan sejarah Indonesia yang dapat diturunkan sesuai dengan kurikulum sejarah di perguruan tinggi LPTK. Di bagian lampiran akan diperkenalkan contoh silabus dalam kurikulum "Pengantar Sejarah Indonesia yang sedang berjalan saat ini.

\section{Penutup}

Kertasi kerja ini telah berupaya menawarkan gagasan-gagasan pendahuluan bagi menyiapkan "peta jalan" bagi pengembangan bahan sejarah Indonesia dalam kurukulum pendidikan sejarah di perguruan tinggi LPTK. Ketersediaan bahan kurikulum sejarah Indonesia itu sendiri hanyalah salah satu persoalan. Persoalan ini tidak hanya muncul dan berdampak terhadap proses belajar dan mengajarkan sejarah Indonesia di perguruan tinggi selama ini, melainkan juga ke sekolah menengah mengingat perguruan tinggi "pencetak guru" adalah sektor hulu yang memerlukan pembenahan terus menerus. Selama persoalan klasik ini tidak terpecahkan secara bersama, selama itu pula kondisi dan isu-isu kritis dalam pembelajaran sejarah di berbagai tingkat pendidikan. Karena itu upaya untuk melahirkan bahan kurikulmun standar untuk perkuliahan Sejarah Indonesia di perguruan tinggi seperti yang sedang diprakarsai seminar ini, jikamberhasil, akan merupakan sumbangan yang amat penting, tidak hanya bagi lembaga pendidikan, melainkan juga bermanfaat untuk anggota masyakat secara keseluruhan. $* * *$

\section{DAFTAR PUSTAKA}

Abdullah, Anzar, "Contemporary History of Indonesia between Historical Truth and Group Purpose in Review of European Studies (November 2015), pp. 179-185.

Abdullah, Taufik, "Historiografi dalam Denyut Sejarah Bangsa, dalam Kalam, 28 (2016), pp. 1-280.

"Pengajaran dan Penelitian Sejarah: Relevance, Kebenaran -- Faktual, Keterangan -- Peristiwa", dalam Jurnal Sejarah, Vol. 1 (1991), pp. 53-61. 
"Masalah Ilmu Sejarah dan Pengajaran Sejarah yang Reflektif dan Inspiratif" dalam Jurnal Sejarah , 6 (1996), pp, 1-16. dan Abdurrahman Surjomihardjo (eds.), Ilmu Sejarah Dan Historiografi: Arah dan Perspektif. Yogyakarta: Ombak, 2016 [edisi pertama Gramedia, 1998).

Alfian, Magdalia, "Pendidikan Sejarah dan Permasalahan yang Dihadapi", Jurnal Ilmiah Kependidikan, Vol. III, No. 2 (Maret 2011)

Caldwell, Malcolm dan Ernst Utrecht, Sejarah Alternatif Indonesia. Yogyakarta:Penerbit: Djaman Baroe, 2011 (544 halaman).

Carr, What is History. New York: Penguin Books Ltd, Harmondsworth, Middlesex, England, 1987 [edisi asli, 1961].

Counsell, C. "Looking through a Josephine-Butler shaped window: focusing pupils' thinking on 'historical significance', Teaching History $114 \quad$ (2004), https://scholar.google.co.id/scholar?q=teaching+History+114+(2004),\&hl= en\&as _sdt $=0 \&$ as_vis $=1 \&$ oi $=$ scholart

Djoko Suryo, "Periodesasi Sejarah Indonesia: Dari Seminar Sejarah di Yogyakarta 1957 hingga Masa Kini" dalam Jurnal Sejarah, Vol. 14, No. 1 (2009), pp.17-31.

Guan, Kwa Chong, "Rewriting Indonesian History. The Future in Indonesia's Past", Working Paper, No. 113, Institute of Defense and Strategic Studies, Singaporee, June 2006.

Hasan, S. Hamid, "Pengembangan Kompetensi Berfikir Kritis Dalam Pembelajaran Sejarah" (2008) sejarah.upi.edu/artikel/dosen/pengembangan- kompetensi-berfikirkritis

"Pendidikan Karakter dalam Pendidikan Sejarah Kurikulum 2013" dalam Prosiding Seminar Nasional: Pembelajaran Sejarah di Tengah Perubahan. Malang: FIS UM kerjasama dengan Asosiasi Pendidikan dan Peneliti Sejarah (2014), pp. 17 -30.

Purwanta, Hieronymus, "The representation of colonial discourse in Indonesian secondary education history textbooks during and after the New Order (19752013)" in History of Education, 47:3 (2018), pp. 349-361.

65 | Seminar Nasional Sejarah ke 4 Jurusan Pendidikan Sejarah Universitas Negeri Padang 
Ismail, Masykur M. "Meninjau Kembali Masa Hindu-Budha di Nusantara dan Gerakan https://www.Alatibibasio'm/dodalament/358795061/Meninjau-_ Kembali-Masa-Hindu-Budha-DiNusantara-InpasOnline-com

Hasan, S. Hamid, "Pengembangan Kompetensi Berfikir Kritis dalam Pembelajaran Sejarah" (2008), sejarah.upi.edu/artikel/dosen/pengembangan-kompetensi- berfikir-kritis "Pendidikan Karakter dalam Pendidikan Sejarah Kurikulum 2013" dalamProsiding Seminar Nasional: Pembelajaran Sejarah di Tengah Perubahan. Malang: FIS UM kerjasama dengan Asosiasi Pendidikan dan Peneliti Sejarah (2014), pp. 17 -30.

Kartodirdjo, Sartono. Pemikiran dan Perkembangan Historiografi Indonesia. Suatu Alternatif. Jakarta: PT Gramedia, 1982.

Pembangunan Bangsa, tentang Nasionalisme, Kesadaran dan Kebudayaan Nasional, Yogyakarta: Aditya Media, 1993.

Sejak Indische sampai Indonesia (Jakarta: Kompas, 2005), hlm. 106-112.

"Tentang Sejarah Nasional Itu!" Majalah TEMPO, 24 Oktober 1992 hlm. $44-66)$.

Rahman, Taufiq, M. “'Indianization' of Indonesia in an Historical Sketch" dalam International Journal of Nusantara, vol. 1, No 2 (2013) , pp. 56-64.

Klooster, H.A.J. Indonesiers Schrijven hun Geschiedent. De Ontwikkeling van de Indonesische Geschiedbeoefening in Theorie en Praktijk, 1900--1980. DordrechtHolland/ Cinnaminson-USA : Foris Publictions. 1985.

Moedjanto, G. “Penulisan Buku Sejarah di Sekolah Menengah” dalam dalam Sri Sutjiatiningsih (ed.) Pengajaran Sejarah (Kumpulan Makalah Simposium). Jakarta: Proyek Inventarisasi dan Dokumentasi Sejarah Nasional Direktorat Sejarah dan Nilai Tradisional Direktorat Jenderal Kebudayaan Departemen Pendidikan dan Kebudayaan, Edisi I 1995, pp. 136-157.

Peursen, C. A. Van, Fakta, Nilai, Peristiwa (Tentang Hubungan antara Ilmu Pengetahuan Ricklefs, M.C. Sejarah Indonesia Moderen, 1200-2008. Jakarta: Serambi, 2010.

Sjamsuddin, Helius "Penulisan Buku Teks Sejarah : Kriteria dan Permasalahannya" dalam 66 | Seminar Nasional Sejarah ke 4 Jurusan Pendidikan Sejarah Universitas Negeri Padang 
Restu Gunawan (ed.), Simposium Pengajaran Sejarah (Kumpulan Makalah

Diskusi). Jakarta: Proyek lnventarisasi dan Dokumentasi Sejarah Nasional

Oirektorat Sejarah dan Nilai Tradisional Direktorat Jenderal Kebudayaan

Departemen Pendidikan dan Kebudayaan, Edisi I 1998, pp. 103-119.

Singgih Tri Sulistiyono, "Historiografi Pembebasan: Suatu Alternatif”, dalam Jurnal Agastya. Vol 6 No 1 (Januari 2016), pp.

Soedjatmoko (et.al.) "Sejarawan Indonesia dan Zamannya: Sebuah Pengantar", dalam Historiografi Indonesia (Terjemahan). Jakarta, PT.Gramedia, 1995.

Soedjatmoko (1976), “Kesadaran Sejarah dan Pembangunan,"dalam Prisma N0.7. Tahun V, Jakarta, LP3ES, pp.. 9-16.

Suwignyo, Agus 'Indonesian National History Textbooks after the New Order. What's New under the Sun?", dalam Bijdragen tot de taal-, land- en volkenkunde (BKI), Vol. 170: Issue 1 (01 Jan 2014), pp. 113-131, https://brill.com/view/journals/bki/ 170/1/article-p113_6.xml?lang =en

Zed, Mestika, "Menggugat Tirani Sejarah Nasional” dimuat dalam Pengantar Filsafat Sejarah. Padang: UNP Press, 2011.

"Clio dan The New History. Humaniora dalam Teori dan Metodologi Sejarah", Historia. Jurnal Pendidikan Sejarah, Vol. II, No. 4 (Des. 2001), pp.

“Karakteristik Berfikir Sejarah” dalam Metodologi Sejarah. Padang, PKSB, 2012.

"Isu-Isu Kritis dan Strategis Pembelajaran Sejarah Dewasa Ini”, Makalah Seminar Peringatan 50 Tahun Seminar Sejarah Nasional I (1957) dengan tema "Historiografi Indonesia: Kilas Balik dan Tantangan Masa Depan”, Cipanas, Jawa Barat 12-14 Desember 2007. Esai ini dapat diakses lewat situs https://visualheritageblog. blogspot.com /2011/09/isu-isu-kritis-dan- strategis.html, Kamis, 08 Sept. 2011.

67 | Seminar Nasional Sejarah ke 4 Jurusan Pendidikan Sejarah Universitas Negeri Padang 
68 | Seminar Nasional Sejarah ke 4 Jurusan Pendidikan Sejarah Universitas Negeri Padang 